\title{
ARTICLE
}

Cite this: DOI: 10.1039/x0xx00000x

Received 00th January 2012, Accepted 00th January 2012

DOI: $10.1039 / \times 0 \times x 00000 x$

www.rsc.org/

\section{Controlling the redox properties of a pyrroloquinolinequinone (PQQ) derivative in a ruthenium(II) coordination sphere}

\author{
Hiroumi Mitome, ${ }^{a}$ Tomoya Ishizuka, ${ }^{a}$ Yoshihito Shiota, ${ }^{b}$ Kazunari Yoshizawa, ${ }^{b, c}$ \\ and Takahiko Kojima* ${ }^{a}$
}

Ruthenium(II) complexes of PQQTME, a trimethyl ester derivative of redox-active PQQ (pyrroloquinolinequinone), were prepared using a tridentate ligand, 2,2':6',2''-terpyridine (terpy) as an auxiliary ligand. Characterization of the complexes was made by spectroscopic methods, X-ray crystallography, and electrochemical measurements. In a complex, the pyridine site of PQQTME binds to the [Ru ${ }^{\mathrm{II}}($ terpy)] unit as a tridentate ligand, and a silver(I) ion is coordinated by the quinone moiety in a bidentate fashion. In contrast, another complex includes the $\left[\mathrm{Ru}^{\mathrm{II}}\right.$ (terpy)] unit at the bidentate quinone moiety of the PQQTME ligand. The difference in the coordination modes between the complexes exhibits characteristic difference in the stability of the metal coordination and also in the reversibility of the reduction processes of the PQQTME ligand. It should be noted that additional metal-ion-binding to the PQQTME ligand largely raises the $1 \mathrm{e}^{-}$-reduction potential of the ligand. In addition, we succeeded in characterization of the $1 \mathrm{e}^{-}$-reduced species of the complexes, where the unpaired electron delocalized in the $\pi$-conjugated system of the PQQTME ${ }^{--}$ligand, using $\mathrm{UV}-\mathrm{V}$ is absorption and ESR spectroscopies.

\section{Introduction}

Pyrroloquinolinequinone (4,5-dihydro-4,5-dioxo-1 $H$-pyrrolo$[2,3-f]$ quinoline-2,7,9-tricarboxylic acid, PQQ) is a redoxactive heteroaromatic coenzyme, which was first detected by Hauge in a glucose dehydrogenase of bacterium anitratum ${ }^{1}$ as the third redox-active coenzyme, following nicotinamide and flavins. Biosynthesis of PQQ is achieved using a peptide precursor containing glutamic acid and tyrosine residues. ${ }^{2}$ PQQ catalytically oxidizes glucose and alcohols at the active sites of quinoproteins as key steps of biological metabolic reactions, and also reduces cytochrome $c$ or azurin through electron transfer. $^{3-5}$ Because of the facts that the catalytic efficiency of PQQ in substrate oxidation is quite high and PQQ utilizes molecular oxygen as a sacrificial oxidant, the exploration of the reaction mechanism of the substrate oxidation by PQQ has attracted considerable attention. ${ }^{6-18}$ X-ray crystallographic analysis of quinoproteins having PQQ as a cofactor shows that the PQQ cofactor is strongly bound to a calcium ion in a tridentate fashion through 5-oxo-O, 6-pyidine-N, and 7carboxylate-O atoms of PQQ (Fig. 1a). ${ }^{19-21}$ Anthony and Richardson have demonstrated that the $\mathrm{Ca}^{2+}$ ion is essential for oxidation of the substrates, using a mutated methanol

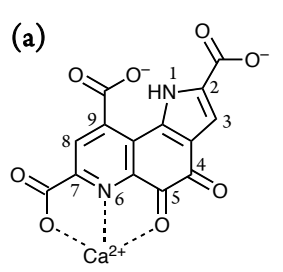

(b)

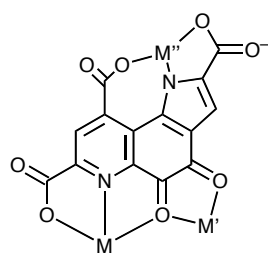

(c)

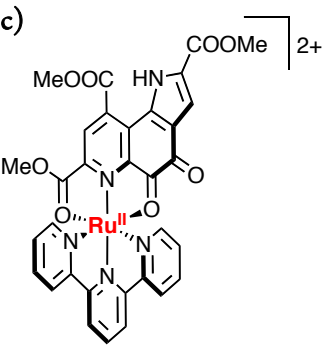

2

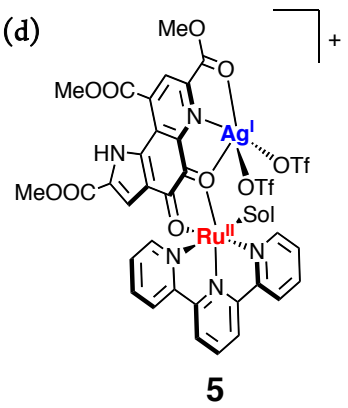

Fig. 1. (a) Structure of a $\mathrm{Ca}^{2+}$-bound PQQ. (b) Three potential metal-coordination sites (M, M', and M") of PQQ. (c) Structure of $\left[\mathrm{Ru}^{\mathrm{II}}\left(\eta^{3}-\mathrm{PQQTME}\right)(\text { terpy) }]^{2+}(\mathbf{2})\right.$. (d) Structure of $\left[\left\{\mathrm{Ru}^{\mathrm{II}}\right.\right.$ (terpy)(sol) $\}\left(\mu \text {-PQQTME) }\left\{\operatorname{Ag}^{\mathrm{I}}(\mathrm{OTf})_{2}\right\}\right]^{+} \quad(\mathbf{5}$, sol $=\mathrm{a}$ coordinating solvent). 
dehydrogenase to lack the $\mathrm{Ca}^{2+}$ ion. ${ }^{22}$ In addition, Itoh and coworkers have revealed the roles of the $\mathrm{Ca}^{2+}$ ion on oxidation reactions catalysed by $\mathrm{PQQ}$ derivatives using the kinetic analyses. $^{12}$ In consequence, the rate constant of the methanol addition at the carbonyl carbon of a trimethyl ester derivative of PQQ (PQQTME) in the presence of $\mathrm{Ca}^{2+}$ ions is accelerated by 3300 times relative to that in the absence of $\mathrm{Ca}^{2+}$ ions, and oxidation of methanol is achieved with addition of a strong base, despite the fact that metal-free PQQ is known to be unable to oxidize methanol in non-enzymatic environments. Additionally, the reduction potential of PQQTME was also positively shifted by $c a .0 .57 \mathrm{~V}$ in the presence of $\mathrm{Ca}^{2+}$ ions. ${ }^{23}$

Since PQQ has several potential metal-coordinating sites in the structure (Fig. 1b), PQQ can act as a ligand in transitionmetal complexes. To elucidate the reactivity of PQQ for substrate oxidation and to clarify roles of the coordinated $\mathrm{Ca}^{2+}$ ion in the biological activity of PQQ, several metal complexes of PQQ and the derivatives have been synthesized and the redox properties of metal-bound PQQ have been investigated. ${ }^{24-}$ 27 For instance, a Cu-PQQTME complex exhibited the reduction potential of the PQQ moiety at $-0.02 \mathrm{~V}$ vs SCE in $\mathrm{CH}_{2} \mathrm{Cl}_{2}$, which was positively shifted by $0.42 \mathrm{~V}$ in comparison with that of free PQQTME. ${ }^{26}$ The properties of metal-PQQ complexes, however, have yet to be well explored, and heteronuclear transition metal complexes of PQQ derivatives had never been reported before our previous work. ${ }^{28}$ Due to the shortage of examples in transition metal complexes of PQQ, it has not been well explored yet how the difference in the coordination sites of PQQ in the transition-metal complexes influences the electrochemical properties of the PQQ ligand and the reactivity in oxidation reactions. To shed light on the point, we herein newly synthesized a $\mathrm{Ru}^{\mathrm{II}}$ complex of PQQTME, 2 and compared the properties with the previously reported $\mathrm{Ru}^{\mathrm{II}}$ PQQTME complex, $5 .^{28}$ Complex 2 has the ONO coordination mode for the $\mathrm{Ru}^{\mathrm{II}}$ coordination, whereas compound $\mathbf{5}$ coordinates to the $\mathrm{Ru}^{\mathrm{II}}$ centre through the $\mathrm{O}-\mathrm{O}$ coordination mode and has an additional $\mathrm{Ag}^{\mathrm{I}}$ ion at the ONO coordination site (Fig. 1c and d). We also examined and compared the reduction potentials and the electronic structures of the PQQTME moieties for $\mathbf{2}$ and $\mathbf{5}$.

\section{Experimental Section}

General. All chemicals available were purchased from appropriate commercial sources and used as received without further purification unless otherwise mentioned. PQQTME, ${ }^{29-32}$ $\left[\mathrm{Ru}^{\mathrm{III}} \mathrm{Cl}_{3} \text { (terpy) }\right]^{32} \quad\left[\left\{(\right.\right.$ terpy $)\left(\mathrm{OH}_{2}\right) \mathrm{Ru}^{\mathrm{II}}(\mu$-PQQTME $) \mathrm{Ag}^{\mathrm{I}}(\mathrm{OTf})-$ $(\mu$-OTf $\left.)\}_{2}\left\{(\mathrm{OTf}) \mathrm{Ag}^{\mathrm{I}}(\mu \text {-OTf })_{2} \mathrm{Ag}^{\mathrm{I}}(\mathrm{OTf})\right\}\right](4),{ }^{28}$ were prepared according to literature procedures. All NMR measurements were performed on JEOL EX-270 and JNM-ECS 400 spectrometers at room temperature. UV-vis absorption spectra were recorded on Shimadzu UV-3600 and UV-2450 spectrophotometers. The electrospray ionization time-of-flight mass (ESI-TOF-MS) spectra were measured on a JEOL JMS$\mathrm{T} 100 \mathrm{CSb}$ mass spectrometer. Electrochemical measurements were performed on a BAS CV-1B electrochemical analyser in freshly distilled THF containing $0.1 \mathrm{M}$ tetrabuthylammonium hexafluorophosphate $\left(\mathrm{TBAPF}_{6}\right)$ as an electrolyte. A small three-electrode cell $(2.0 \mathrm{~mL})$ was used with a platinum-disk working electrode and a platinum wire as the counter electrode.
The potentials were measured with respect to the $\mathrm{Ag} / \mathrm{AgNO}_{3}$ reference electrode and all of the potentials (vs $\mathrm{Ag} / \mathrm{AgNO}_{3}$ ) were calibrated with ferrocene/ferrocenium ${ }^{++}(+0.23 \mathrm{~V}$ vs $\left.\mathrm{Ag} / \mathrm{AgNO}_{3}\right)$ and then converted to values vs SCE by adding $0.30 \mathrm{~V} .^{33}$ All of electrochemical measurements were carried out under an atmospheric pressure of argon at room temperature. ESR spectra were recorded on a Bruker EMXPlus 9.5/2.7 spectrometer at $95 \mathrm{~K}$, controlled by ER $4131 \mathrm{VT}$ and ER $4141 \mathrm{VT}$ temperature-control modules using liquid $\mathrm{N}_{2}$.

Synthesis of [(terpy)Ru ${ }^{\mathrm{II}}\left(\boldsymbol{\mu}\right.$-PQQTME)Ag ${ }^{\mathrm{I}}\left(\mathrm{OTf}_{2}\right]$ (OTf) (1·OTf). The chlorido ligands of $\mathrm{Ru}^{\mathrm{III}} \mathrm{Cl}_{3}$ (terpy) were substituted with a solvent molecule by a modified procedure of the Thibault's methods. ${ }^{35}$ To a dried Schlenk tube, $\mathrm{RuCl}_{3}$ (terpy) (5.9 mg, $13 \mu \mathrm{mol})$, AgOTf (11.7 mg, $51.6 \mu \mathrm{mol})$, and then deaerated $\mathrm{H}_{2} \mathrm{O}(5 \mathrm{~mL})$ were added under argon atmosphere. The mixture was stirred at $55{ }^{\circ} \mathrm{C}$ for $60 \mathrm{~min}$, cooled down to room temperature, and then filtered through a membrane to remove precipitated $\mathrm{AgCl}$. The brown filtrate was dried in vacuo at $<40{ }^{\circ} \mathrm{C}$ for several hours to give green solid of crude $\left[\mathrm{Ru}^{\text {II }}\right.$ (terpy) $\left.\left(\mathrm{OH}_{2}\right)_{3}\right](\mathrm{OTf})_{2}$. To the solid was added PQQTME $(5.1 \mathrm{mg}, 14 \mu \mathrm{mol})$ and dry 1,2-dichroloethane $(10 \mathrm{~mL})$, and the mixture was heated at reflux for $11 \mathrm{~h}$ under argon atmosphere. The reaction mixture was cooled down to room temperature, filtered and washed with dichloromethane. Concentration of the filtrate under ambient pressure for 2 weeks gave green crystals and brown filtrate and collection of the green crystals gave the title compound. Yield: $10.0 \mathrm{mg}(7.93 \mu \mathrm{mol}, 61 \%)$. Anal.: Calcd. for $\mathrm{C}_{32} \mathrm{H}_{23} \mathrm{~N}_{5} \mathrm{O}_{8} \mathrm{RuAg} \cdot 3 \mathrm{CF}_{3} \mathrm{SO}_{3} \cdot 2 \mathrm{CH}_{2} \mathrm{Cl}_{2} \cdot 7 \mathrm{H}_{2} \mathrm{O}$ : C, 28.53; $\mathrm{H}$, 2.65 ; N, 4.50. Found: C, 28.50; H, 2.41; N, 4.76.

Conversion of 1 into $\left[\mathrm{Ru}^{\mathrm{II}}\left(\boldsymbol{\eta}^{3}-\mathrm{PQQTME}\right)(\text { terpy) }]^{2+}\right.$ (2). Dissolving 1. OTf in $\mathrm{MeCN}$ gave a green solution of 2. ESITOF-MS (MeCN): $m / z=353.6$ (calcd. for [Ru(PQQTME)(terpy) $\left.]^{2+}: m / z=353.5\right) .{ }^{1} \mathrm{H} \mathrm{NMR}\left(\mathrm{CD}_{3} \mathrm{CN}\right): \delta 3.91(\mathrm{~s}, 3 \mathrm{H}$, COOMe), 3.97 (s, 3H, COOMe), 4.22 (s, 3H, 7-COOMe of PQQTME), 7.30 (d, $J=2.2 \mathrm{~Hz}, 1 \mathrm{H}, \mathrm{H} 3$ of PQQTME), 7.48 (ddd, $J=7.7,5.5,1.1 \mathrm{~Hz} 2 \mathrm{H}, \mathrm{H} 5$ of terpy), 7.81 (dd, $J=5.5$, $1.1 \mathrm{~Hz}, 2 \mathrm{H}, \mathrm{H} 6$ of terpy), $8.12(\mathrm{td}, J=7.8,1.1 \mathrm{~Hz}, 2 \mathrm{H}, \mathrm{H} 4$ of terpy), 8.39 (t, $J=7.9 \mathrm{~Hz}, 1 \mathrm{H}, \mathrm{H} 4$ ' of terpy), 8.42 (dd, $J=7.9$, $1.1 \mathrm{~Hz}, 2 \mathrm{H}, \mathrm{H} 3$ of terpy), 8.54 (d, $J=7.9 \mathrm{~Hz}, 2 \mathrm{H}, \mathrm{H} 3$ ' of terpy), 9.08 (s, 1H, H8 of PQQTME), $12.82(\mathrm{br} \mathrm{s}, 1 \mathrm{H}, \mathrm{H} 1 \mathrm{of}$ PQQTME). UV-Vis (DMF at $\left.-20{ }^{\circ} \mathrm{C}\right): \lambda_{\max }[\mathrm{nm}]=705,476$, $377,338$.

Conversion of 2 into [Ru II (terpy)( $\eta^{2}$-PQQTME)(MeCN)] $\left(\mathbf{P F}_{\mathbf{6}}\right)_{2}$ (3). Dissolving 1. OTf into MeCN solution of TBAPF 6 gave a green solution of $\mathbf{2}$ as mentioned above. A single crystal of $\left[\mathrm{Ru}^{\mathrm{II}} \text { (terpy)(PQQTME)(MeCN)]( } \mathrm{PF}_{6}\right)_{2}$ (3) was obtained by slow concentration of the solution for several days in the presence of $\mathrm{CHCl}_{3}$ vapour as a poor solubility solvent. This incorporation of the poor solubility solvent into the solution could cause reduction of solubility of the complex and the appearance of crystals. HR-MS (MeCN): $374.0428\left(\mathrm{M}^{2+}\right.$, calcd for $\mathrm{C}_{34} \mathrm{H}_{26} \mathrm{~N}_{6} \mathrm{O}_{8} \mathrm{Ru}$ ), 374.0444 (found). ${ }^{1} \mathrm{H} \mathrm{NMR}\left(\mathrm{CD}_{3} \mathrm{CN}\right): \delta$ 3.91 (s, 3H, COOMe), 3.99 (s, 3H, COOMe), 4.10 (s, 3H, 7COOMe of PQQTME), $7.35(\mathrm{~d}, J=2.2 \mathrm{~Hz}, 1 \mathrm{H}, \mathrm{H} 3$ of PQQTME), 7.48 (ddd, $J=6.6,5.5,2.2 \mathrm{~Hz} \mathrm{2H,} \mathrm{H5} \mathrm{of} \mathrm{terpy),}$ 8.17 (ddd, $J=8.6,6.6,1.6 \mathrm{~Hz}, 2 \mathrm{H}, \mathrm{H} 4$ of terpy), 8.37 (t, $J=8.2$ 
Scheme 1. Syntheses of $\mathrm{Ru}^{\mathrm{II}}-\mathrm{Ag}^{\mathrm{I}}-\mathrm{PQQTME}$ and $\mathrm{Ru}^{\mathrm{II}}-\mathrm{PQQTME}$ Complexes

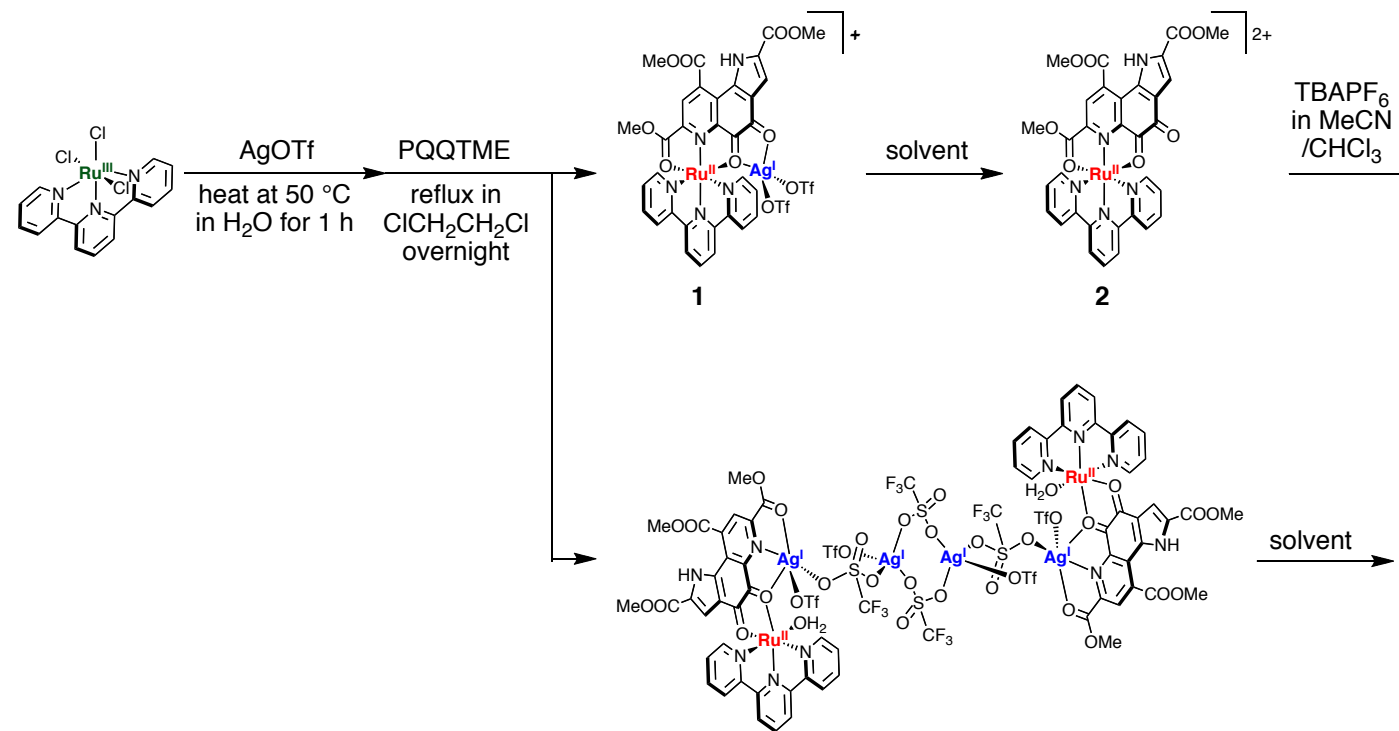

4
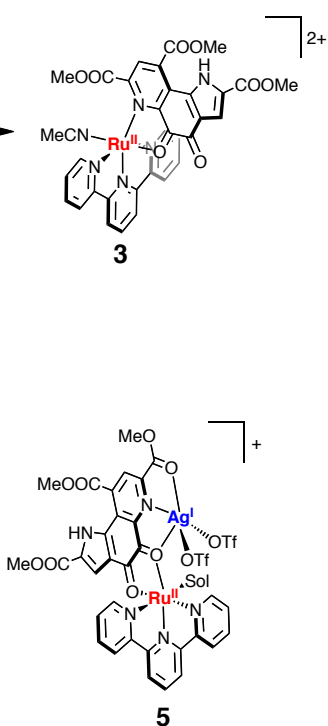

$\mathrm{Hz}, 1 \mathrm{H}, \mathrm{H} 4{ }^{\prime}$ of terpy), 8.39 (d, $J=8.6 \mathrm{~Hz}, 2 \mathrm{H}, \mathrm{H} 3$ of terpy), $8.62\left(\mathrm{~d}, J=8.2 \mathrm{~Hz}, 2 \mathrm{H}, \mathrm{H} 3{ }^{\prime}\right.$ of terpy), 8.73 (s, 1H, H8 of PQQTME), 8.89 (dd, $J=5.5,1.6 \mathrm{~Hz}, 2 \mathrm{H}, \mathrm{H} 6$ of terpy). X-ray diffraction measurement of 3 was performed at $120 \mathrm{~K}$ on a Bruker APEXII diffractometer. The structure was solved by a direct method (SIR-97) and expanded with a differential Fourier technique. All non-hydrogen atoms were refined anisotropically and the refinement was carried out with full matrix least squares on $F$. All calculations were performed by using Yadokari-XG. ${ }^{36}$ Crystallographic data: $\mathrm{C}_{34} \mathrm{H}_{26} \mathrm{~F}_{12} \mathrm{~N}_{6} \mathrm{O}_{8} \mathrm{P}_{2} \mathrm{Ru}, F W=1037.61$, green, monoclinic, $P 2_{1} / n$, $a=27.114(3) \AA, b=12.8194(16) \AA, c=33.802(4) \AA, \beta=$ $98.429(2)^{\circ}, V=11622.2(3) \AA^{3}, Z=8, D_{\text {calc }}=1.186 \mathrm{~g} / \mathrm{cm}^{3}, F_{000}$ $=4144, R 1=0.0686(I>2.00 \sigma(I)), w R 2=0.0888$ (all data), $\mathrm{GOF}=1.065$.

Computational method. The structures of free PQQTME, 1, 2, one-electron reduced species of $\mathbf{2}\left(\left[\mathrm{Ru}^{\mathrm{II}}\left(\mathrm{PQQTME}^{\circ}\right)(\text { terpy })\right]^{+}\right.$, $\mathbf{5}$, and one-electron reduced species of $\mathbf{5}\left(\left[\left\{\mathrm{Ru}^{\mathrm{II}}(\right.\right.\right.$ terpy $\left.)\left(\mathrm{OH}_{2}\right)\right\}-$ $\left.\left.\left(\mathrm{PQQTME}^{*}\right)\left\{\operatorname{Ag}^{\mathrm{I}}(\mathrm{OTf})_{2}\right\}\right]\right)$ were optimized by using the B3LYP functional. ${ }^{37}$ The SDD basis set ${ }^{38}$ was used for $\mathrm{Ru}$ and $\mathrm{Ag}$ atoms and the $\mathrm{D} 95^{* *}$ basis $\mathrm{set}^{39}$ for $\mathrm{H}, \mathrm{C}, \mathrm{N}, \mathrm{F}$, and $\mathrm{S}$ atoms. The Gaussian 09 program package ${ }^{40}$ was used for all DFT calculations.

\section{Result and Discussion}

Syntheses of PQQ Complexes. In this work, we employed $2,2^{\prime}: 6^{\prime}, 2^{\prime}$ '-terpyridine (terpy) as an auxiliary ligand of a $\mathrm{Ru}^{\mathrm{II}}$ ion, since terpy is a strongly $\pi$-accepting ligand and thus $d \pi$ electrons of the $\mathrm{Ru}^{\mathrm{II}}$ centre are donated to the terpy ligand by $\pi$ back bonding. Therefore, the back donation of the $d \pi$ electrons of the $\mathrm{Ru}^{\mathrm{II}}$ centre to the PQQ ligand should be reduced and thus the electron density of the PQQ moiety is expected to be lowered and more electron-deficient. PQQTME was synthesized with 4-amino-2-hydroxybenzoic acid as a starting material by the reported procedure. ${ }^{29-32} \mathrm{Ru}^{\mathrm{II}}$-PQQTME complexes used in this study were prepared in good yields from PQQTME and $\left[\mathrm{Ru}^{\mathrm{II}}(\right.$ terpy $\left.)\left(\mathrm{OH}_{2}\right)_{3}\right](\mathrm{OTf})_{2}$, which was prepared by treatment of $\left[\mathrm{Ru}^{\mathrm{III}} \mathrm{Cl}_{3}\right.$ (terpy)] with excess amount of $\mathrm{Ag}^{\mathrm{I}}(\mathrm{OTf})$ in $\mathrm{H}_{2} \mathrm{O}$ (Scheme 1). ${ }^{34}$ The resulting aqueous solution of $\left[\mathrm{Ru}^{\mathrm{II}}\right.$ (terpy) $\left.\left(\mathrm{OH}_{2}\right)_{3}\right](\mathrm{OTf})_{2}$ was filtered, and dried up under vacuum to obtain a mixture of $\left[\mathrm{Ru}^{\mathrm{II}}(\right.$ terpy $\left.)\left(\mathrm{OH}_{2}\right)_{3}\right](\mathrm{OTf})_{2}$ and excessive silver salts. The mixture was heated overnight at reflux together with PQQTME in 1,2-dichloroethane, and then, the resulting suspension was filtered. The filtrate was slowly concentrated to afford crystals of a $\mathrm{Ru}^{\mathrm{II}}-\mathrm{Ag}^{\mathrm{I}}-\mathrm{PQQTME}$ heteromultinuclear complex. Interestingly, the amount of $\mathrm{Ag}^{\mathrm{I}}(\mathrm{OTf})$ used for the preparation of $\left[\mathrm{Ru}^{\mathrm{II}}(\right.$ terpy $\left.)\left(\mathrm{OH}_{2}\right)_{3}\right](\mathrm{OTf})_{2}$ controlled the products of the reaction of PQQTME with $\left[\mathrm{Ru}^{\mathrm{II}}\right.$ (terpy) $\left.\left(\mathrm{OH}_{2}\right)_{3}\right](\mathrm{OTf})_{2}$. Using 4 equiv. of $\mathrm{Ag}^{\mathrm{I}}(\mathrm{OTf})$ per ruthenium, a dinuclear complex, [(terpy) Ru ${ }^{\mathrm{II}}(\mu$-PQQTME)$\left.\operatorname{Ag}^{\mathrm{I}}\left(\mathrm{OTf}_{2}\right)\right](\mathrm{OTf})_{2}(\mathbf{1})$ was obtained, whereas usage of 7 equiv. of $\mathrm{Ag}^{\mathrm{I}}(\mathrm{OTf})$ per ruthenium gave a hexanuclear complex, $\left[\left\{(\text { terpy })\left(\mathrm{OH}_{2}\right) \mathrm{Ru}^{\mathrm{II}}(\mu \text {-PQQTME }) \mathrm{Ag}^{\mathrm{I}}(\mathrm{OTf})(\mu \text {-OTf })\right\}_{2}\{(\mathrm{OTf})-\right.$ $\left.\left.\operatorname{Ag}^{\mathrm{I}}(\mu \text {-OTf })_{2} \operatorname{Ag}^{\mathrm{I}}(\mathrm{OTf})\right\}\right](4){ }^{28}$

The structure of $\mathbf{1}$ was deduced from the results of the elemental analysis for the solid sample of $\mathbf{1}$, the spectroscopic data of $\mathbf{2}$, and the crystal structure of $\mathbf{3}$ (Fig. 3). The result of the elemental analysis indicates that the solid of 1 contains an $\mathrm{Ag}(\mathrm{OTf})_{3}$ unit per a $\mathrm{Ru}^{\mathrm{II}}(\mathrm{PQQTME})($ terpy) unit. In addition, relevance to the crystal structure of $\mathbf{3}$, the $\mathrm{Ru}^{\mathrm{II}}$ (terpy) unit of $\mathbf{1}$ is considered to be coordinated to the ONO coordination site of the PQQTME ligand. The solid of $\mathbf{1}$ was dissolved in a coordinating solvent such as $\mathrm{MeCN}$ to give the mononuclear $\mathrm{Ru}$ II complex, 2 .

Spectroscopic Characterization of Ru'-PQQTME Complexes. In the ${ }^{1} \mathrm{H}$ NMR spectrum of 2 in $\mathrm{CD}_{3} \mathrm{CN}$ (Fig. S1 in ESI), the ${ }^{1} \mathrm{H}$ NMR signal of the methoxycarbonyl group at the 7'-position of the PQQTME ligand appeared at $\delta 4.22 \mathrm{ppm}$, which was downfield-shifted in comparison with that of free 
PQQTME ( $\delta 4.00 \mathrm{ppm})$ due to the coordination to the $\mathrm{Ru}^{\mathrm{II}}$ ion. A similar downfield shift was also observed for the PQQTME$\mathrm{Ca}^{2+}$ complex reported by Itoh and coworkers. ${ }^{12 \mathrm{a}}$

The ESI-TOF-MS spectrum of 2 in acetonitrile $(\mathrm{MeCN})$ showed peak clusters at $m / z=337.6,353.6,358.1,707.2$ and 738.1. All of those clusters exhibited distribution patterns corresponding to species having one ruthenium and no sliver atom (Fig. S2 in ESI). The former three peak clusters showed peak separations of 0.5 , whereas those of the latter two of them were 1.0. Hence, we assumed that 1 loses the $\mathrm{Ag}^{\mathrm{I}}$ ion to give the mononuclear complex, $\mathbf{2}$, upon being dissolved in a coordinating solvent such as $\mathrm{MeCN}$, as shown in Scheme 1. The peak clusters at $m / z=353.6$ and 707.2 were assigned to 2 (calcd. for $\left[\mathrm{Ru}^{\mathrm{II}}\left(\eta^{3} \text {-PQQTME)(terpy) }\right]^{2+}: m / z=353.5\right)$ and $1 \mathrm{e}^{-}$ reduced species of $\mathbf{2}$, (calcd. for $\left[\mathrm{Ru}^{\mathrm{II}}\left(\eta^{3}-\mathrm{PQQTME}^{-}\right) \text {(terpy) }\right]^{+}$: $m / z=707.1)$, respectively. Thus, we propose that the complex 2 derived from 1 in MeCN should be $\left[\mathrm{Ru}(\text { terpy)(PQQTME) }]^{2+}\right.$, in which both terpy and PQQTME bind to the $\mathrm{Ru}^{\mathrm{II}}$ centre as tridentate ligands in the meridional geometry as shown in Scheme 1. The peak clusters at $m / z=337.6$ and 358.1 can be ascribed to fragment signals of 2: the former should be derived from the fragment species that complex 2 loses a methoxy group and one proton from the PQQTME moiety (calcd. for $\left[\mathrm{Ru}^{\mathrm{II}}(\mathrm{PQQTME}-\mathrm{H}-\mathrm{OMe})(\text { terpy)}]^{2+}: m / z=337.5\right)$, and the latter can be assigned to the species that $\mathbf{2}$ loses a methoxy group and one proton from the PQQTME moiety and then induces additional coordination of an acetonitrile molecule (calcd. for $\left[\mathrm{Ru}^{\mathrm{II}}(\mathrm{PQQTME}-\mathrm{H}-\mathrm{OMe})(\text { terpy) }(\mathrm{MeCN})]^{2+}: m / z\right.$ = 358.0). The methoxycarbonyl group at the 7'-position of the PQQTME moiety in $\mathbf{2}$ is possibly activated by coordination to the $\mathrm{Ru}^{\mathrm{II}}$ centre and is apt to be cleaved between the oxygen atom of the methoxy group and the carbon atom of the carbonyl group at 7'-position of the PQQTME moiety during ionization processes for ESI-TOF-MS measurements (Fig. S3 in ESI). The cleavage gave the fragment showing a signal at $\mathrm{m} / \mathrm{z}=337.6$. In addition, the complex losing the methoxy group can be attacked by an acetonitrile molecule from the solvent at the $\mathrm{Ru}^{\mathrm{II}}$ centre, to give the peak cluster at $m / z=358.0$, which has been

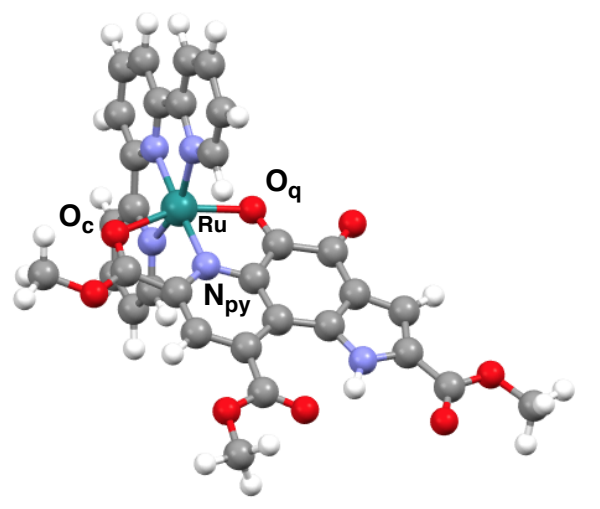

Fig 2. DFT-optimized structure of the cation part of 2 at the B3LYP level. $\mathrm{O}_{\mathrm{q}}, \mathrm{O}_{\mathrm{c}}$, and $\mathrm{N}_{\mathrm{py}}$ denote the Ru-bound quinone oxygen, the Ru-bound carbonyl oxygen, and the Ru-bound pyridine nitrogen of the PQQTME ligand, respectively. mentioned above. We did not observe the mass signal derived from acetonitrile-coordinating species without the loss of the methoxy group of PQQTME in the ESI-TOF-MS measurements, suggesting that acetonitrile molecules cannot coordinate to the $\mathrm{Ru}^{\mathrm{II}}$ centre of $\mathbf{2}$ under mild conditions, even in the acetonitrile solution. The peak cluster at 738.1 was assigned to $[\mathbf{2}+\mathrm{OMe}]^{+}$ion (calcd. for $\left\{\left[\mathrm{Ru}^{\mathrm{II}}(\mathrm{PQQTME}-\mathrm{OMe})(\text { terpy })\right]\right\}^{+}$: $m / z=738.1$. Since the carbonyl group at the 5-position of PQQ has high reactivity toward nucleophilic attacks and furthermore the reactivity is enhanced by metal coordination in 2 , the methoxy group is probably added at the carbonyl carbon of the 5-position of the PQQTME moiety during the ionization. ${ }^{12 b, 41,42}$

Based on the ${ }^{1} \mathrm{H}$ NMR and mass spectroscopic data, we concluded that 1 lost the $\mathrm{Ag}^{\mathrm{I}}$ ion in a coordinating solvent such as $\mathrm{MeCN}$ to give complex 2, but no further reaction occurred including solvent coordination to the $\mathrm{Ru}^{\mathrm{II}}$ centre (Scheme 1). In contrast to $\mathbf{2}$, the PQQTME moiety in $\mathbf{5}$ coordinates both to the $\mathrm{Ru}^{\mathrm{II}}$ and $\mathrm{Ag}^{\mathrm{I}}$ ions even in a coordinating solvent (Scheme 1). ${ }^{28}$ This difference in the stability of $\mathrm{Ag}^{\mathrm{I}}$ coordination can be attributed to the number of coordinating atoms: PQQTME in complex 1 behaves as a bidentate ligand to the $\mathrm{Ag}^{\mathrm{I}}$ ion, whereas that in $\mathbf{5}$ acts as a tridentate one.

DFT Calculations on 2. We conducted density functional theory (DFT) calculations on $\mathbf{2}$ to shed light on the geometrical and electronic structures. The optimized structure is shown in Fig. 2. The bond lengths of $\mathrm{Ru}-\mathrm{O}_{\mathrm{q}}, \mathrm{Ru}-\mathrm{O}_{\mathrm{c}}$, and $\mathrm{Ru}-\mathrm{N}_{\mathrm{p}}$ were estimated to be $2.078 \AA, 2.189 \AA$, and $1.975 \AA$, respectively. The LUMO of 2 was revealed to be $\pi^{*}$ orbital of the quinone moiety of the PQQTME ligand as shown in Fig. S4 (ESI). In comparison with the LUMO of $\mathbf{5},{ }^{28}$ there are only slight differences between the LUMOs of 2 and 5: both the LUMOs are $\pi^{*}$ orbitals of the PQQTME ligand.

We also conducted calculation on free PQQTME molecule to discuss $\pi$-back bonding from $\mathrm{Ru}^{\mathrm{II}}$ centre to PQQTME in $\mathbf{2}$ through comparison of the lengths of coordinating carbonyl C$\mathrm{O}$ double bond between free PQQTME and 2. In optimized structure of free PQQTME (Fig. S5 in ESI), the lengths of the

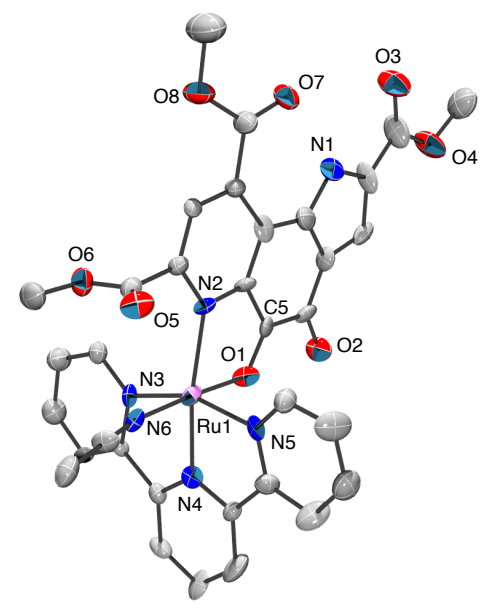

Fig. 3. An ORTEP drawing of the cation part of $\mathbf{3}$ with atom labelling. 
$\mathrm{C}=\mathrm{O}$ double bonds of the two carbonyl groups, which coordinate to the $\mathrm{Ru}^{\mathrm{II}}$ centre in $\mathbf{2}$, are $1.211 \AA$ (quinone) and $1.210 \AA$ (ester), respectively. On the other hand, the corresponding lengths in the optimized structure of 2 are 1.262 $\AA$ (quinone) and $1.257 \AA$ (ester). The difference in the bond lengths indicates the $\pi$-back bonding from the $\mathrm{Ru}^{\mathrm{II}}$ centre to the PQQTME ligand in 2.

Crystal Structure of [Ru ${ }^{I I}($ terpy)(PQQTME) $(\mathrm{MeCN})] \cdot \mathbf{2 P F}_{6}$ $\left(\mathbf{3} \cdot \mathbf{2 P F}_{6}\right)$. Slow concentration of a solution of $\mathbf{2}$ in acetonitrile containing $\mathrm{TBAPF}_{6}$ in the presence of diffused $\mathrm{CHCl}_{3}$ vapour gave a green crystal suitable for X-ray crystallography. The crystal contains two independent cation parts of $\left[\mathrm{Ru}^{\mathrm{II}}\right.$ (terpy) $\left(\eta^{2}-\right.$ PQQTME)(MeCN) $]^{2+}(3)$, which exhibits dissociation of the methoxycarbonyl group at the 7 ' position from the $\mathrm{Ru}^{\mathrm{II}}$ centre and has a coordinated acetonitrile molecule to the $\mathrm{Ru}^{\mathrm{II}}$ centre (Scheme 1), and four hexafluorophosphate anions. The structure of one of the cations is depicted in Fig. 3 with selected atom labelling. The cation parts are chemically equivalent, except slight structural differences caused by the crystal packing. Since the replacement of the methoxycarbonyl group in 2 to an $\mathrm{MeCN}$ molecule was not observed in the ${ }^{1} \mathrm{H}$ NMR spectra of $\mathbf{2}$ measured at a few hours later after dissolving $\mathbf{2}$ in $\mathrm{CD}_{3} \mathrm{CN}$, we assumed that the substitution slowly occurred during the crystallization taking over ten days.

Here, we discuss details of the crystal structure of $\mathbf{3}$ using one of the two independent cation parts, containing Ru1 atom. Selected bond lengths $(\AA)$ and angles $\left(^{\circ}\right)$ of $\mathbf{3}$ are listed in Table $\mathrm{S} 1$ in (ESI). The geometry around the $\mathrm{Ru}^{\mathrm{II}}$ ion in $\mathbf{3}$ is a distorted octahedron having terpy as a tridentate ligand and the PQQTME ligand binds to the $\mathrm{Ru}^{\mathrm{II}}$ centre as a neutral bidentate ligand, where the $\mathrm{N}$ (pyridine) and $\mathrm{O}$ (quinone) coordinates to the $\mathrm{Ru}^{\mathrm{II}}$ centre. A MeCN molecule occupies the last coordination site of the $\mathrm{Ru}^{\mathrm{II}}$ centre, by substituting the methoxycarbonyl $\mathrm{O}$ atom at the 7'-position of the PQQTME ligand. The dissociation of the carbonyl $\mathrm{O}$ atom should be due to the weak coordination as reported for a $\mathrm{Cu}^{\mathrm{I}}$-PQQTME complex, in which the coordination bond length has been reported to be the longest $(2.579(4) \AA)$ among other coordination bonds involved. ${ }^{26}$ As mentioned above, the DFToptimized structure of 2 (Fig. 2) also showed the longest bond length for $\mathrm{Ru}-\mathrm{O}_{\mathrm{c}}(2.189 \AA)$ to support the possibility of the dissociation of the methoxycarbonyl oxygen toward the coordination of $\mathrm{MeCN}$, which should bind strongly to a $\mathrm{Ru}^{\mathrm{II}}$ centre. ${ }^{43}$ In addition, the longer bond length of the metalcoordinating carbonyl bond (C5-O1, 1.27(1) $\AA$ ) was observed than those of the $\mathrm{Cu}^{\mathrm{I}}$-PQQTME complex $(1.222(8) \AA)^{26}$ and

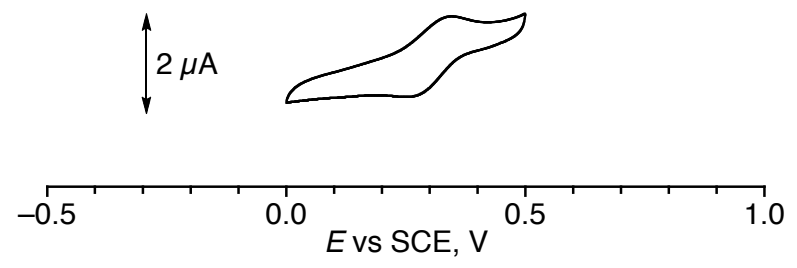

Fig. 4. Cyclic voltammogram of 2 in THF containing $0.1 \mathrm{M}$ $\mathrm{TBAPF}_{6}$ at room temperature. those of natural methanol dehydrogenases (1.24 $\AA$, defined as the semiquinone radical forms). ${ }^{19 \mathrm{~d}}$ This result suggests certain contribution of $\pi$-back bonding from the $d \pi$ orbitals of the $\mathrm{Ru}^{\mathrm{II}}$ centre to the $\pi^{*}$ orbitals of the PQQTME moiety, which resides mainly on the quinone moiety including the $\mathrm{C}=\mathrm{O}$ double bond (Fig. S4 in ESI). The smaller bond angle of N2-Ru1-N4 $\left(168.4(3)^{\circ}\right)$ relative to that of $\mathrm{O} 1-\mathrm{Ru} 1-\mathrm{N} 6\left(176.9(3)^{\circ}\right)$ indicates steric repulsion between the methoxycarbonyl group at the 7'position of the PQQTME moiety and the coordinating acetonitrile, which results in the lean of the PQQTME ligand to the direction of the $\mathrm{O} 1$ side. The crystal structure of $\mathbf{3}$ exhibits a completely different coordination mode of PQQTME from that in 4, which has one $\mathrm{Ag}^{\mathrm{I}}$ ion at the $\mathrm{O}$ (methoxycarbonyl)$\mathrm{N}$ (pyridine)-O(quinone) coordination site and one $\mathrm{Ru}^{\mathrm{II}}$ ion at the o-quinone coordination site of the PQQTME moiety (Scheme 1). ${ }^{28}$ In addition, an intramolecular hydrogen bond was found between $\mathrm{N} 1-\mathrm{H} \cdot \cdots \mathrm{O} 7$ with the interatomic distance of 2.61(1) $\AA$ for $\mathrm{N} 1 \cdots \mathrm{O} 7$ separation.

Electrochemical Measurements on 2. Cyclic voltammetry (CV) and differential pulse voltammetry (DPV) of 2 were measured in THF containing $0.1 \mathrm{M} \mathrm{TBAPF}_{6}$ as a supporting electrolyte at room temperature under $\mathrm{Ar}$ atmosphere. In the measurements, the rest potential was found to be $+0.77 \mathrm{~V}$ vs SCE and complex 2 exhibited a reversible reduction wave at $+0.28 \mathrm{~V}$ vs SCE with a peak separation value $\left(E_{\mathrm{pc}}-E_{\mathrm{pa}}\right)$ of 64 $\mathrm{mV}$ (Fig. 4). We assigned the wave to $1 \mathrm{e}^{-}$reduction of the quinone moiety of the PQQTME ligand in $\mathbf{2}$, based on the results of DFT calculations on $\mathbf{2}$ and absorption spectra of chemically reduced $\mathbf{2}$ (see above). The reduction potential exhibited a larger positive shift from that of free PQQTME $\left(E_{\text {red }}\right.$ $=-0.53 \mathrm{~V}$ vs $\mathrm{SCE}$ in $\mathrm{MeCN})^{23}$ and even larger than that observed for a mononuclear $\mathrm{Cu}^{\mathrm{I}}$ - PQQTME complex $\left(E_{1 / 2}=-\right.$ $0.02 \mathrm{~V}$ vs SCE),${ }^{26}$ because of the high electron acceptability of the $\mathrm{Ru}^{\mathrm{II}}$-terpy unit. As for the $\mathrm{Ru}^{\mathrm{II}}$ centre, no redox processes could be observed in the potential window of the $\mathrm{MeCN}$ solution of 2 (up to $c a$. $+1.6 \mathrm{~V}$ ). Since the redox potential of $\mathrm{Ru}^{\mathrm{II}} / \mathrm{Ru}{ }^{\mathrm{III}}$ couple for $\left[\mathrm{Ru}^{\mathrm{II}}(\text { terpy })_{2}\right]^{2+}$ has been reported to be $+1.38 \mathrm{~V}$ (vs SCE) ${ }^{44}$ the PQQTME ligand should act as a stronger $\pi$-acceptor than terpy in the $\mathrm{Ru}^{\mathrm{II}}$ coordination sphere.

On the other hand, CV of 5 in THF showed one irreversible reduction wave at $E_{\mathrm{pc}}=+0.42 \mathrm{~V}$ vs $\mathrm{SCE},{ }^{28}$ and the reduction potential was determined to be $+0.50 \mathrm{~V}$ vs SCE using the peak potential of DPV, which is higher than that of 2 by $0.22 \mathrm{~V}$. For $\mathbf{5}$, no redox wave derived from the $\mathrm{Ru}^{\mathrm{II}}$ centre was observed as in the case of $\mathbf{2}$. The difference of the redox potentials between 2 and 5 can be ascribed to the number of metal ions binding to the PQQTME ligand and also difference of the coordination (a)

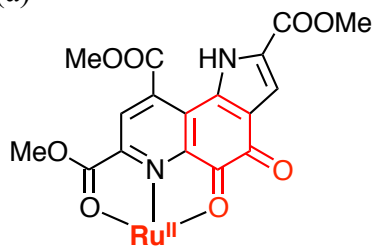

(b)

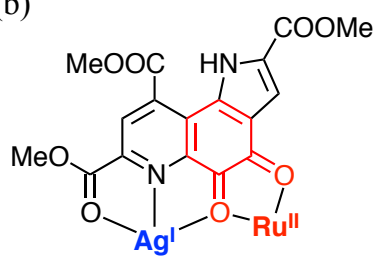

Fig. 5. Schematic description of the difference of coordination modes between $\mathbf{2}$ (a) and $\mathbf{5}$ (b). 
modes as depicted in Fig 5: complex 2 has one $\mathrm{Ru}^{\mathrm{II}}$ ion at the ONO coordination site of the PQQTME ligand, which is not fully conjugated with the quinone moiety that acts as the electron-accepting site for the reduction process. In contrast, complex 5 holds two transition metal ions at the quinone moiety, one of which is a $\mathrm{Ag}^{\mathrm{I}}$ ion at the ONO coordination site in a monodentate fashion and the other is $\mathrm{a} \mathrm{Ru}^{\mathrm{II}}$ ion at the quinone moiety in a bidentate mode. DFT calculations indicated that the LUMO levels of $2(-9.11 \mathrm{eV})$ was comparable to that of $\left[\mathrm{Ru}^{\mathrm{II}} \text { (terpy)(PQQTME) }\left(\mathrm{H}_{2} \mathrm{O}\right)\right]^{2+}(-9.07$ $\mathrm{eV})$, which is a model compound of $\mathbf{5}$ without the $\left[\mathrm{Ag}^{\mathrm{I}}(\mathrm{OTf})_{2}\right]^{-}$ unit. This result suggests that, without $\mathrm{Ag}^{\mathrm{I}}$ binding, the reduction potential of $\mathbf{5}$ should be comparable to that of $\mathbf{2}$, in sharp contrast to the fact described above. Note that the OTf ions bound to $\mathrm{Ag}^{\mathrm{I}}$ should be prone to be substituted by $\mathrm{THF}$ molecules in the THF solution used for the electrochemical measurements. Therefore, the higher reduction potential should be derived from the binding of $\mathrm{Ag}^{\mathrm{I}}$ ion as a Lewis acid to support the $\mathrm{Ag}^{\mathrm{I}}$ binding in the proposed structure of 5 as depicted in Scheme 1 and Fig 5. Thus, we conclude that the $\mathrm{Ag}^{\mathrm{I}}$ binding to the ONO moiety of PQQTME has a strong impact on the raise of the reduction potential of PQQTME.

The difference of reversibility in the reduction waves between 2 and 5 also can be explained by difference in the coordination modes. Since the $\mathrm{Ru}^{\mathrm{II}}$ ion in $\mathbf{2}$ is bound at the ONO coordination site of the PQQTME ligand, the coordination bonds should be strong because of the three-point chelation and the strong $\pi$-acceptability of PQQTME. On the other hand, the $\mathrm{Ru}^{\mathrm{II}}$ ion of $\mathbf{5}$ is bonded only with the two quinone-O atoms. Although the $1 \mathrm{e}^{-}$reduction of 5 strengthen $\sigma$ donation from the carbonyl oxygen atoms of the quinone moiety to the $\mathrm{Ru}^{\mathrm{II}}$ centre, the effect should be compensated by reduction of the $\pi$-acceptability of the quinone moiety. Thus, the effect of this strengthened $\sigma$-donation on reversibility of the redox process is probably limited. Therefore, the reason for the irreversibility of the reduction wave observed for $\mathbf{5}$ can be ascribed to weakness of the coordination bonds in 5 . In consequence, the difference in the coordination modes between $\mathbf{2}$ and $\mathbf{5}$ causes not only difference in the reduction potentials
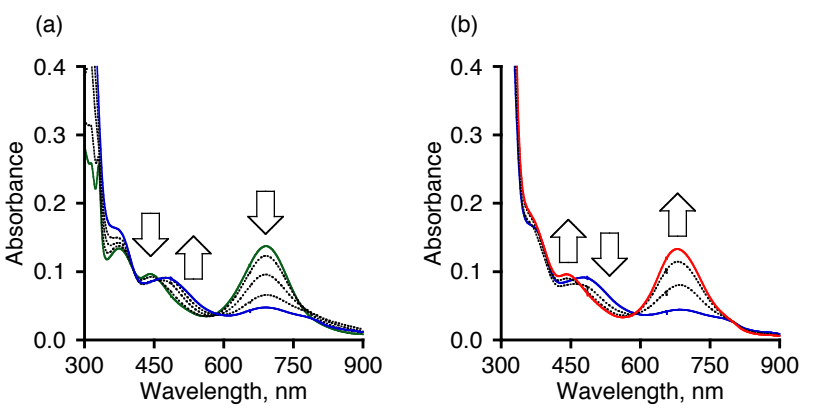

Fig. 6. $U V-v i s$ spectral changes of 2 upon reduction in $\mathrm{MeCN}$ at $0{ }^{\circ} \mathrm{C}$. (a) Titration of DecFc (0 (green) - 1 eq (blue) ) and (b) reoxidation with addition of tris(4-bromophenyl)aminium hexachloroantimonate (0 (blue) - 1 eq (red)). but also that in stability of $1 \mathrm{e}^{-}$-reduced forms of $\mathbf{2}$ and $\mathbf{5}$.

Chemical Reduction of 2. To elucidate the characteristics of $1 \mathrm{e}^{-}$-reduced 2 , which showed fairly good reversibility in the reduction process (Fig 4), we measured absorption spectra of $\mathbf{2}$ upon addition of decamethylferrocene $(\mathrm{DecFc})\left(E_{\mathrm{ox}}=-0.08 \mathrm{~V}\right.$ vs $\mathrm{SCE}$ in $\mathrm{MeCN})$ as a reductant. ${ }^{45}$ The absorption spectrum of 2 in $\mathrm{MeCN}$ at $0{ }^{\circ} \mathrm{C}$ under $\mathrm{Ar}$ atmosphere exhibited absorption maxima at 374, 441, and $691 \mathrm{~nm}$. The latter two absorption bands can be assigned to metal-to-ligand charge transfer (MLCT) bands from $d_{\pi}$ orbitals of the $\mathrm{Ru}^{\mathrm{II}}$ ion to the $\pi^{*}$ orbitals of the terpy ligand $(441 \mathrm{~nm})$ and the PQQTME ligand $(691 \mathrm{~nm})$, based on comparison with UV-vis absorption bands of $\mathbf{5}^{28}$ Upon addition of 1 equiv of DecFc into the solution of 2 in $\mathrm{MeCN}$ at $0{ }^{\circ} \mathrm{C}$, the MLCT band of the $\mathrm{Ru}^{\mathrm{II}}$ centre to the terpy ligand was shifted to $475 \mathrm{~nm}$, and the MLCT bands due to CT from the $\mathrm{Ru}^{\mathrm{II}}$ centre to the PQQTME ligand at $691 \mathrm{~nm}$ disappeared with showing isosbestic points at 405, 458, and $584 \mathrm{~nm}$ (Fig. 6a). Additionally, the original spectrum was recovered by adding tris(4-bromophenyl)-aminium hexachloroantimonate as a $1 \mathrm{e}^{-}$oxidant to the solution of $1 \mathrm{e}^{-}-$ reduced 2 (Fig. 6b), indicating that the redox process is highly reversible as expected from the $\mathrm{CV}$ of 2 (Fig. 4). We assume that the disappearance of the longer MLCT band should be caused by the raised energy level of the LUMO of the $1 \mathrm{e}^{-}-$ reduced PQQTME ligand. Additionally, it is suggested that the $1 \mathrm{e}^{-}$reduction of the PQQTME moiety destabilizes the $d \pi$ level of the $\mathrm{Ru}^{\mathrm{II}}$ centre to cause the red shift of the MLCT band from the $\mathrm{Ru}^{\mathrm{II}}$ centre to the terpy ligand.

ESR Measurements on Chemically Reduced 2. The electronic structure of the $1 \mathrm{e}^{-}$-reduced species of $\mathbf{2}$ was investigated by ESR measurements at $95 \mathrm{~K}$ in the frozen $\mathrm{MeCN}$ solution, which was prepared by treatment of $\mathbf{2}$ with DecFc as a reductant (Fig. 7). In the ESR spectrum, a signal was observed at $g=2.006$, indicating the formation of a $\mathrm{Ru}^{\mathrm{II}}$-bound organic radical, that is, $\mathrm{PQQTME}^{\circ}$. Kaim and co-workers have reported that the ESR spectrum of a $1 \mathrm{e}^{-}$-reduced $\mathrm{Ru}^{\mathrm{II}}-\mathrm{PQQ}$ complex. ${ }^{27}$ The $1 \mathrm{e}^{-}$-reduced 2 showed a similar ESR signal to that of Kaim's complex and the ESR spectrum of $1 \mathrm{e}^{-}$-reduced 2 was also very similar to that of $1 \mathrm{e}^{-}$-reduced $\mathbf{5}$ in frozen THF, formed by the reaction of $\mathbf{5}$ with DecFc as a reductant. ${ }^{28}$ Thus, we conclude that the $1 \mathrm{e}^{-}$reduction of $\mathbf{2}$ and $\mathbf{5}$ affords the identical electronic structure, that is, a semiquinone radical anion state of the $\mathrm{Ru}^{\mathrm{II}}$-PQQTME complex.

We performed DFT calculations on $1 \mathrm{e}^{-}$-reduced 2 to

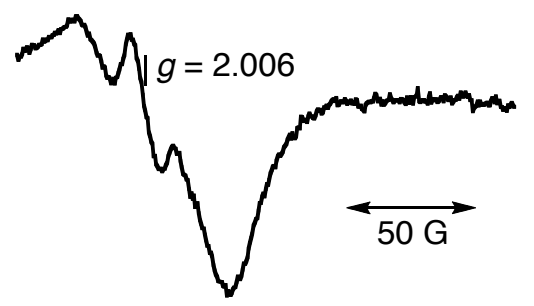

Fig. 7. ESR spectrum of $\left[\mathrm{Ru}^{\mathrm{II}}\left(\mathrm{PQQTME}^{\bullet-}\right)(\text { terpy) }]^{+}\right.$, generated by the chemical reduction of $\mathbf{2}$ with $\mathrm{DecFc}$ in $\mathrm{MeCN}$ (measured at $95 \mathrm{~K}$ ). 
elucidate the electronic structure of the reduced species and the redox properties of the PQQTME ligand in $\mathbf{2}$. The calculations suggest that the SOMO of $1 \mathrm{e}^{-}$-reduced 2 shows $\pi^{*}$ character and delocalizes over the PQQTME moiety (Fig. 8). This result indicates that $1 \mathrm{e}^{-}$reduction of 2 occurs on the PQQTME ligand similarly to that of $5^{28}$ The similarity of the SOMOs of 2 and 5 is well matched to the results of the ESR measurements of $1 \mathrm{e}^{-}-$ reduced $\mathbf{2}$ and $\mathbf{5}$, in which the signals observed are very similar to each other. These results indicate that the difference in coordination modes between $\mathbf{2}$ and $\mathbf{5}$ does not affect the electronic structures of the PQQTME ${ }^{\cdot-}$ ligand, despite that it affects the stability of the $1 \mathrm{e}^{-}$-reduced species as reflected on the reversibility of the $1-\mathrm{e}^{-}$reduction process and the electron acceptability, that is, redox potentials of the PQQTME ligand. (a)

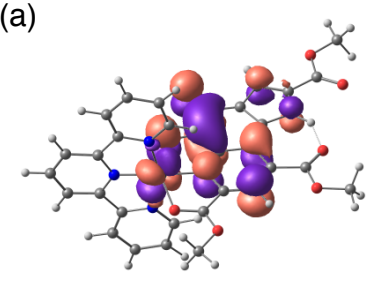

(b)

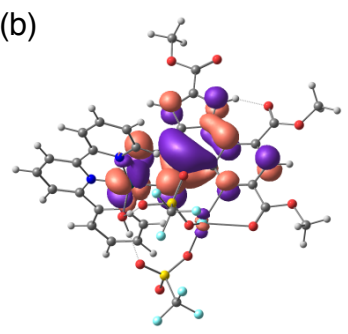

Fig 8. DFT-calculated SOMOs of $1 \mathrm{e}^{-}$reduced 2 (a) and $\mathbf{5}(\mathrm{b})$.

\section{Conclusions}

We have described the synthesis and characterization of $\mathrm{Ru}^{\mathrm{II}}-\mathrm{PQQTME}$ complexes. In complexes $\mathbf{1}, \mathbf{2}$, and $\mathbf{3}$, the $\mathrm{Ru}^{\mathrm{II}}$ ion is bound to the PQQTME ligand through the ONO coordination site, whereas the $\mathrm{Ru}^{\mathrm{II}}$ ion coordinates to the quinone moiety of the PQQTME ligand in $\mathbf{4}$ and $\mathbf{5}$. The PQQTME ligand in $\mathbf{2}$ and $\mathbf{5}$ exhibited higher reduction potentials in comparison with those of PQQ cofactors in natural enzymes and also those of reported metal-PQQ complexes, reflecting the high electron-acceptability of the $\mathrm{Ru}^{\mathrm{II}}$-terpy unit. The difference in coordination modes between $\mathbf{2}$ and $\mathbf{5}$ causes differences of the physical properties between the complexes. For instance, the difference in strength of the coordination mode causes that in stability of the reduced form of $\mathbf{2}$ and $\mathbf{5}$. In addition, the PQQTME moiety in $\mathbf{5}$ shows a higher reduction potential than that in $\mathbf{2}$, despite having the similar electronic structures in $1 \mathrm{e}^{-}$-reduced form. The difference in the reduction potentials has been revealed to be mainly derived from the $\mathrm{Ag}^{\mathrm{I}}-$ ion binding to the tridentate ONO-bay moiety of the PQQTME ligand in $\mathbf{5}$ as a Lewis acid. This finding is fully consistent with the $\mathrm{Ca}^{2+}$-binding to the same position in the natural enzymes such as methanol dehydrogenases.

\section{Acknowledgements}

This work was supported by Grants-in-Aids (No 24245011) from the Japan Society of Promotion of Science (JSPS, MEXT) of Japan. Financial supports are also appreciated from The Asahi Glass Foundation and The Mitsubishi Foundation.

\section{Notes and references}

a Department of Chemistry, University of Tsukuba, 1-1-1 Tennoudai, Tsukuba, Ibaraki 305-8571, Japan

${ }^{b}$ Institute for Materials Chemistry and Engineering and International Research Centre for Molecular System, Kyushu University, Moto-oka, Nishi-Ku, Fukuoka 819-0395, Japan

c Elements Strategy Initiative for Catalysts \& Batteries, Kyoto University, Nishikyo-Ku, Kyoto 615-8520, Japan

$\dagger$ Electronic Supplementary Information (ESI) available: ${ }^{1} \mathrm{H}$ NMR spectra of PQQTME and 2; ESI-TOF-MS spectrum of 2; a proposed mechanism of reaction occurring upon ionization for ESI-TOF-MS measurements of 2; the frontier orbitals of $\mathbf{2}$ and $\mathbf{5}$ calculated at the B3LYP level; the optimized structure of PQQTME molecule at the B3LYP level; selected bond lengths ( $(\AA)$ and angles $\left({ }^{\circ}\right)$ of 3; Cartesian coordinates of optimized structure of $\mathbf{1}, \mathbf{2}, \mathbf{5}, \mathbf{2}^{--}, \mathbf{5}^{-}$and PQQTME. CCDC 1031557. For ESI and crystallographic data in CIF or other electronic format see DOI: 10.1039/b000000x/

1 J. G. Hauge, J. Biol. Chem., 1964, 239, 3630.

2 (a) O. T. Mangnusson, H. Toyama, M. Saeki, R. Schwarzenbacher and J. P. Klinman, J. Am. Chem. Soc., 2004, 126, 5342; (b) O. T. Mangnusson, J. M. RoseFigura, H. Toyama, R. Schwarzenbacher and J. P. Klinman, Biochemistry, 2007, 46, 7174; (c) J. M. RoseFigura, S. Puehringer, R. Schwarzenbacher, H. Toyama and J. P. Klinman, Biochemistry, 2011, 50, 1556; (d) Y.-O. Shen, F. Bonnot, E. M. Imsand, J. M. RoseFigura, K. Sjölander and J. P. Klinman, Biochemistry, 2012, 51, 2265; (e) F. Bonnot, A. T. Iavarone and J. P. Klinman, Biochemistry, 2013, 52, 4667; (f) J. P. Klinman, and F. Bonnot, Chem. Rev., 2014, 114, 4343.

3 C. Anthony, Biochem. J., 1996, 320, 697.

4 (a) V. L. Davidson, M. A. Kumar and J. Wu, Biochemistry, 1992, 31, 1504; (b) T. K. Harris and V. L. Davidson, Biochemistry, 1993, 32, 4362; (c) T. K. Harris and V. L. Davidson, Biochemistry, 1993, 32, 14145; (d) T. K. Harris, V. L. Davidson, L. Chen, F. S. Mathews and Z.-X. Xia, Biochemistry, 1994, 33, 12600; (e) V. L. Davidson, Acc. Chem. Res., 2000, 33, 87; (f) V. L. Davidson, Arch. Biochem. Biophys., 2004, 428, 32.

5 (a) A. Oubrie, H. J. Rozeboom, K. H. Kalk, A. J. J. Olsthoorn, J. A. Duine and B. W. Dijkstra, EMBO J., 1999, 18, 5187; (d) A. Oubrie and B. W. Dijkstra, Protein Science, 2000, 9, 1265.

6 Y. Ohshiro, S. Itoh, K. Kurokawa, J. Kato, T. Hirano and T. Agawa, Tetrahedron Lett., 1983, 24, 3465.

7 S. Itoh, N. Kato, Y. Ohshiro and T. Agawa, Tetrahedron Lett., 1984, 25, 4753 .

8 S. Itoh, N. Kato, M. Mure and Y. Ohshiro, Bull. Chem. Soc. Jpn., $1987,60,420$.

9 S. Itoh, M. Mure and Y. Ohshiro, J. Chem. Soc., Chem. Commun., 1987, 1580.

10 E. J. Rodriguez and T. C. Bruice, J. Am. Chem. Soc., 1989, 111, 7947.

11 S. Itoh, M. Mure, M. Ogino and Y. Ohshiro, J. Org. Chem., 1991, 56, 6857.

12 (a) S. Itoh, H. Kawakami and S. Fukuzumi, J. Am. Chem. Soc., 1997, 119, 439; (b) S. Itoh, H. Kawakami and S. Fukuzumi, Biochemistry, 1998, 37, 6562; (c) S. Itoh, H. Kawakami and S. Fukuzumi, J. Mol. Catal. B: Enzymatic, 2000, 8, 85. 
13 S. Fukuzumi, S. Itoh, T. Komori, T. Suenobu, A. Ishida, M. Fujitsuka and O. Ito, J. Am. Chem. Soc., 2000, 122, 8435.

14 T. S. Eckert and T. C. Bruice, J. Am. Chem. Soc., 1983, 105, 4431.

15 A. Oubrie, H. J. Rozeboom, K. H. Kalk, J. J. Olsthoorn, J. A. Duine and B. W. Dijkstra, EMBO J., 1999, 18, 5187.

16 Y.-J. Zheng, Z.-X. Xia, Z.-W. Chen, F. S. Mathews and T. C. Bruice, Proc. Natl. Acad. Sci. USA, 2001, 98, 432.

17 S. Y. Reddy and T. C. Bruice, J. Am. Chem. Soc., 2003, 125, 8141.

18 M. Leopoldini, N. Russo and M. Toscano, Chem.-Eur. J., 2007, 13, 2109.

19 (a) S. White, G. Boyd, F. S. Mathews, Z.-X. Xia, W.-W. Dai, Y.-F. Zhang and V. L. Davidson, Biochemistry, 1993, 32, 12955; (b) Z.-X. Xia, W.-W. Dai, Y.-F. Zhang, S. A. White, G. D. Boyd and F. S. Mathews, J. Mol. Biol., 1996, 259, 480; (c) Z.-X. Xia, Y.-N. He, W.W. Dai, S. A. White, G. D. Boyd and F. S. Mathews Biochemistry, 1999, 38, 1214; (d) M. Ghosh, C. Anthony, K. Harlos, M. G. Goodwin and C. Blake, Structure, 1995, 3, 177.

20 (a) A. Oubrie, H. J. Rozeboom, K. H. Kalk, A. J. J. Olsthoorn, J. A. Duine and B. W. Dijkstra, EMBO J., 1999, 18, 5187; (b) A. Oubrie, H. J. Rozeboom and B. W. Dijkstra, Proc. Natl. Acad. Sci. USA, 1999, 96, 11787 .

21 A. Oubrie, H. J. Rozeboom, K. H. Kalk, E. G. Huizinga and B. W. Dijkstra, J. Biol. Chem., 2002, 277, 3727.

22 I. W. Richardson and C. Anthony, Biochem. J., 1992, 287, 709.

23 S. Itoh, H. Kawakami and S. Fukuzumi, J. Am. Chem. Soc., 1998, 120, 7271 .

24 (a) S. Suzuki, T. Sakurai, S. Itoh and Y. Ohshiro, Chem. Lett., 1988, 777; (b) S. Suzuki, T. Sakurai, S. Itoh and T. Ohshiro, Inorg. Chem. 1988, 27, 591 .

25 N. Nakamura, T. Kohzuma, H. Kuma and S. Suzuki, Inorg. Chem., 1994, 33, 1594.

26 M. Wanner, T. Sixt, K.-W. Klinkhammer and W. Kaim, Inorg. Chem., 1999, 38, 2753.

27 B. Schwederski, V. Kasack, W. Kaim, E. Roth and J. Jordanov, Angew. Chem., Int. Ed. Engl., 1990, 29, 78.

28 H. Mitome, T. Ishizuka, Y. Shiota, K. Yoshizawa and T. Kojima, Inorg. Chem., 2013, 52, 2274.

29 A. R. MacKenzie, C. J. Moody and C. W. Roes, Tetrahedron, 1986, 42, 3259.

30 F. G. Glansdorp, R. J. Spandl, J. E. Swatten, O. Loiseleur, M. Welch and D. R. Spring, Org. Biomol. Chem., 2008, 6, 4120.

31 C. N. Carrigan, R. D. Bartlett, C. S. Esslinger, K. A. Cybulski, P. Tongcharoensirikul, R. J. Bridges, C. M. Thompson, J. Med. Chem., 2002, 45, 2260.

32 P. F. Alewood, S. A. Hussian, T. C. Jenkins, M. J. Perkins, A. H. Sharma, N. P. Y. Siew and P. Ward, J. Chem. Soc., Perkin Trans. 1, 1978, 1066.

33 B. P. Sullivan, J. M. Calvert and T. J. Meyer, Inorg. Chem., 1980, 19, 1404.

34 C. K. Mann and K. K. Barnes, Electrochemical Reactions in Nonaqueous Systems, Mercel Dekker: New York, 1970.

35 D. Taher, M. E. Thibault, D. D. Mondo, M. Jennings and M. Schlaf, Chem.-Eur. J., 2009, 15, 10132.

36 (a) T. Wakita, Yadokari-XG, Software for Crystal Structure Analysis, 2001. (b) C. Kabuto, S. Akine, T. Nemoto and E. Kwon, Release of
Software (Yadokari-XG 2009) for Crystal Structure Analyses. J. Cryst. Soc. Jpn., 2009, 51, 218.

37 (a) A. D. Becke, Phys. Rev. A, 1988, 38, 3098. (b) C. Lee, W. Yang and R. G. Parr, Phys. Rev. B, 1988, 37, 785. (c) A. D. Becke, J. Chem. Phys., 1993, 98, 5648.

38 D. Andrae, U. Haussermann, M. Dolg, H. Stoll and H. Preuss, Theor. Chim. Acta, 1990, 77, 123.

39 (a) K. Raghavachari and G. W. Trucks, J. Chem. Phys., 1989, 91, 1062; (b) T. H. Dunning, J. P. Hay, In Modern Theoretical Chemistry; H. F. Schaefer, III, Ed.; Plenum: New York, 1976; Vol. 3, pp 1-27.

40 Gaussian 09 (Revision A.02), Gaussian, Inc., Wallingford CT, 2009.

41 W. R. Browne, N. M. O’Boyle, J. J. McGarvey and J. G. Vos, Chem. Soc. Rev., 2005, 34, 641.

42 S. Itoh, M. Ogino, Y. Fukui, H. Murano, M. Komatsu, Y. Ohshiro, T. Inoue, Y. Kai and N. Kasai, J. Am. Chem. Soc., 1993, 115, 9960.

43 (a) T. Kojima, K. Hayashi, Y. Tachi, Y. Naruta, T. Suzuki, K. Uezu, Y. Shiota and K. Yoshizawa, Bull. Chem. Soc. Jpn., 2005, 78, 2152. (b) T. Kojima, T. Morimoto, T. Sakamoto, S. Miyazaki and S. Fukuzumi, Chem.-Eur. J. 2008, 14, 8904.

44 Y. Liu, R. Hammitt, D. A. Lutterman, R. P. Thummel and C. Turro, Inorg. Chem., 2007, 46, 6011.

45 E. Fourie, J. C. Swarts, I. Chambrier and M. J. Cook, Dalton Trans. 2009,1145 